\title{
PERTUMBUHAN DAN PRODUKSI BAWANG MERAH (Allium ascalonicum L.) BERBASIS APLIKASI BIOURINE SAPI
}

\author{
GROWTH AND PRODUCTION OF ONION (Allium ascalonicum L.) BASED ON \\ APPLICATION OF COW BIOURINE
}

\author{
Olvie G. Tandi1), Jeanne Paulus ${ }^{2)}$ dan Arthur Pinaria2) \\ 1)Balai Pengkajian Teknologi Pertanian Sulawesi Utara \\ 2)Fakultas Pertanian Unsrat Manado, 95115
}

\begin{abstract}
The research aims to assess the response to the growth and production of onion against of liquid organic fertilizer from cow biourie in some concentrations and to get the best concentration for the growth and production of red onion. The research was conducted atfield experimental in Pandu, North Minahasa regency from May to July 2014. The experiment was designed using a randomized block design. The treatment was concentration of cow biourine namely $0 \%\left(B_{1}\right) 10 \%,\left(B_{2}\right) 20 \%,\left(B_{3}\right) 30 \%$, $\left(B_{4}\right)$ $40 \%$ and $\left(B_{5}\right) 50 \%$. Each treatment was replicated three times. Characters observed were plant height, number of leaves, tuber diameter, number of tuber, fresh weight of tuber with leaves and dry weight of tuber. Data was analyzed using analysis of variance. The result showed that the biourine concentration had significant effect on plant height, number of leaves, tuber diameter, number of tuber, fresh weight of tuber with leaves and dry weight of tuber. Treatment of $B_{1}, B_{2}, B_{3}$ and $B_{4}$ concentration were not significant difference at plant height. However, those four treatments were significantly different compared to $B_{0}$ and $B_{5}$. The fives treatment differed with the control on characters of number of leaves, number of tuber andfresh weight of tuber with leaves. On character of tuber dry weight, $B_{2}$ treatment was significant difference compared to control whereas the other treatments were not significantly differed. On character of tuber diameter, three treatments were significant difference compared to the control namely $\mathrm{B}_{2}, \mathrm{~B}_{4}$ and $\mathrm{B}_{5}$.
\end{abstract}

Keywords : Allium ascalonicum L, biourine cow, fertilizer, growth and production

\section{ABSTRAK}

Penelitian bertujuan mengkaji respon pertumbuhan dan produksi bawang merah terhadap pemberian pupuk organik dari biourine sapi pada berbagai konsenrtasi dan mendapatkan konsentrasi terbaik untuk pertumbuhan dan produksi bawang merah. Penelitian ini dilakukan di Kebun Percobaan di Pandu, Kabupaten Minahasa Utara dari Mei hingga Juli 2014. Penelitian dirancang dengan menggunakan rancangan acak kelompok.Perlakuan konsentrasi biourine sapi yaitu $0 \%\left(B_{1}\right) 10 \%,\left(B_{2}\right) 20 \%,\left(B_{3}\right) 30 \%$, $\left(B_{4}\right) 40 \%$ dan $\left(B_{5}\right) 50 \%$.Setiap perlakuan diulang tiga kali. Karakter yang diamati adalah tinggi tanaman, jumlah daun, diameter umbi, jumlah umbi, berat umbi segardengan daun dan berat umbi kering. Data dianalisis menggunakan analisis varian. Hasil penelitian menunjukkan bahwa konsentrasi biourine memiliki pengaruh yang signifikan terhadap tinggi tanaman, jumlah daun, diameter umbi, jumlah umbi, berat umbi segardengan daun dan berat umbi kering dengan daun. Perlakuan konsetrasi $B_{1}, B_{2}, B_{3}$ dan $B_{4}$ tidak ada perbedaan yang signifikan pada tinggi tanaman. Namun, empat perlakuan berbeda secara signifikan dibandingkan dengan $\mathrm{B}_{0}$ dan $\mathrm{B}_{5}$. Lima perlakuan berbeda nyata dengan kontrol pada karakter jumlah daun, jumlah umbi dan berat segar umbi dengan daun. Pada karakter berat umbi kering dengan daun, perlakuan $B_{2}$ berbeda secara signifikan dibandingkan dengan kontrol sedangkan perlakuan lainnya tidak berbeda secara signifikan. Pada karakter diameter umbi, tiga perlakuanyaitu $B_{2}$, $\mathrm{B}_{4}$ dan $\mathrm{B}_{5}$ memberikan pengaruh yang signifikan dibanding dengan kontrol.

Kata kunci : Allium ascalonicum L, biourine sapi, pemupukan, pertumbuhan dan produksi 


\section{PENDAHULUAN}

Bawang merah (Allium ascalonicum L.) merupakan salah satu komoditas utama sayurandi Indonesia dan mempunyai banyak manfaat. Bawang termasuk ke dalam kelompok rempah tidak bersubtitusi yang berfungsi sebagai bumbu penyedap makanan serta bahan obat tradisional. Berdasarkan data dari the National Nutrient Database bawang merah memiliki kandungan karbohidrat, gula, asam lemak, protein dan mineral lainnya yang dibutuhkan oleh tubuh manusia (Waluyo dan Sinaga, 2015).

Pengembangan bawang merah di Sulawesi Utara tersebar di beberapa kabupaten dan kota seperti: Minahasa, Minahasa Selatan, Minahasa Tenggara, Minahasa Utara, Bolaang Mongondow, Bolang Mongondow Timur, Kota Kotamobagu dan Kota Bitung. Daerah-daerah ini tersebar di dataran rendah sampai dataran tinggi atau memiliki ketinggian tempat dari $0-800 \mathrm{mdpl}$ (Dinas Pertanian dan Peternakan Provinsi Sulawesi Utara, 2014).

Keberadaan hewan ternak di Sulawesi Utara, sebagian besar belum dikelola sesuai peruntukannya dan terkesan dipelihara secara liar (ada yang diikat/dilepas pada lahan-lahan kosong). Berdasarkan hal tersebut di atas, maka dipandang perlunya sistem pertanian terpadu antara ternak dan sayuran yang dapat diterapkan di kawasan ini. Pertanian terpadu hortikultura dan ternak dapat mengurangi biaya produksi karena sisa sayuran akan dimanfaatkan sebagai pakan ternak, sedangkan kotoran ternak dapat dijadikan pupuk organic bagi tanaman hortikultura.

Produksi umbi bawang merah dengan daun tahun 2012 di Sulawesi Utara sebesar 5,301 ton dengan luas panen sebesar 680 hektar dan rata-rata produktivitas sebesar 7,80 ton/ha. Pada tingkat Nasional, rata-rata produksi bawang merah mencapai 10,7 tha. Potensi hasil di tingkat Balai Penelitian Sayuran (Balitsa) Lembang untuk dua varietas Sembrani dan Trisula.yang ditanam pada kebun visitor plot. Varietas Sembrani, potensi hasil 9,0-24,4 ton/ha, dan dapat beradaptasi dengan baik di dataran rendah dengan altitude $6-80 \mathrm{~m}$ dpl. Sedangkan varietas Trisula potensi hasil 6.50-23.21 ton/ha (Badan Litbang Pertanian, 2013b). Berdasarkan data tersebut di atas menunjukkan produksi rata-rata bawang merah di Sulawesi Utara masih jauh berbeda dibandingkan dengan rata-rata Nasional maupun di tingkat Litbang Pertanian dan produksi masih berpeluang untuk dapat ditingkatkan.

Beberapa penelitian yang memanfaatkan biourine sapi sebagai pupuk organik yang dikombinasikan dengan pupuk anorganik dapat meningkatkan hasil tanaman. Menurut Sutari (2010) bahwa biourine sapi dengan konsentrasi $200 \mathrm{ml} / \mathrm{ha}$ air menunjukkan hasil tanaman sawi hijau yang paling baik. Penelitian Adijaya (2008), kombinasi pupuk organik padat dan pupuk organik cair (RB $5 \mathrm{t} \mathrm{ha}^{-1}+$ 7500 I ha $^{-1}$ urine sapi, konsentrasi 20\%) memberikan produksi bawang merah tertinggi sebesar 10,37 ton ha- ${ }^{-1}$ atau meningkat sebesar $60,77 \%$ dibandingkan dengan tanpa pupuk organik.

Penelitin ini bertujuan mengkaji respon pertumbuhan dan produksi bawang merah terhadap pemberian pupuk organik dari biourine sapi pada berbagai konsentrasi dan mendapatkan konsetrasi biourine sapi terbaik untuk pertumbuhan dan produksi bawang merah.

\section{METODE PENELITIAN}

Penelitian dilaksanakan di Pandu selama tiga bulan terhitung mulai bulan Mei 2014 sampai dengan Juli 2014.

Bahan digunakan pada penelitian ini yaitu bawang merah varietas Bima yang diperoleh dari pedagang benih di Pasar Bersehati Manado, pupuk Ponska, SP-36, Pupuk kotoran ayam, dan bahan untuk membuat biourie sapi: urea, EM-4, temulawak, kunyit, jahe, gula pasir dan urin sapi segar. Alat yang digunakan berupa: cangkul, sekop, meteran, timbangan, gelon sebagai wadah urine sapi, drum plastik berkapasitas 200 liter, gelas ukur, ember plastik, gembor, kamera dan alat tulis menulis.

Penelitian menggunakan Rancangan Acak Kelompok (RAK). Susunan perlakuan terdiri atas 6 perlakuan dan 3 ulangan sehingga terdapat 18 plot dengan ukuran $4 \mathrm{~m} \times 1,2 \mathrm{~m}$. Masing-masing perlakuan konsentrasi biourine adalah sebagai berikut: 

Kontrol $\left(B_{0}\right), 10 \%$
$\left(B_{1}\right), 20 \%$
$\left(B_{2}\right), 30 \%$
$\left(B_{3}\right), 40 \%$
$\left(B_{4}\right)$ dan $50 \%\left(B_{5}\right)$.

\section{Prosedur Kerja}

Tahapan yang dilakukan dalam pelaksanaan penelitian ini adalah sebagai berikut:

\section{Persiapan}

Kegiatan di awali dengan proses pembuatan urine segar menjadi biourine lewat fermentasi. Menurut Pustaka Indonesia (2008) proses pembuatan urine menjadi biourine dengan proses fermentasi: 1) EM-4 sebagai stater fermenter $250 \mathrm{ml}$, gula pasir $1 \mathrm{~kg}$, urea $1 \mathrm{~kg}$ dilarutkan dalam air jernih sebanyak 10 liter kemudian masukkan ke dalam drum yang berisi urine segar sebanyak 150 liter. 2) Lengkuas, kencur, kunyit, temulawak dan jahe masing-masing $0,5 \mathrm{~kg}$ dihancurkan dan masukan juga ke dalam drum urine. Setelah tercampur kemudian urine diaduk sampai rata selama 15 menit, kemudian drum plastik ditutup rapat. 3) Lakukan pengadukan setiap hari selama 15 menit dan kemudian drum ditutup rapat kembali selama tujuh hari. 4) Setelah tujuh hari urine dipompa dengan menggunakan pompa yang biasa dipakai pada aquarium untuk meniriskan urine dan dilewatkan melalui talang plastik dengan panjang $2 \mathrm{~m}$ yang dibuat seperti tangga selama 3 jam, tujuan proses ini untuk penipisan atau menguapkan kandungan gas amoniak, agar tidak berbahaya bagi tanaman yang akan diberi pupuk biourine tersebut. Kemudian pupuk cair ini siap digunakan. Urine sapi sebelum difermentasi warnanya coklat kekuningkuningan, baunya masih berbau urine, tetapi setelah difermentasi menjadi biourine warnanya berubah menjadi coklat kehitam-hitaman, dan sudah tidak berbau urine.

\section{Pengolahan Tanah}

Lahan pertanian dibersihkan dari gulma dan tanaman pengganggu lainnya, kemudian diolah sampai gembur menggunakan traktor. Setelah itu dibuat plot percobaan ukuran $4 \mathrm{~m} \times 1,2 \mathrm{~m}$ dengan ketinggian $20-30 \mathrm{~cm}$, jarak antar bedengan adalah $40 \mathrm{~cm}$. Luas plot percobaan adalah $4,8 \mathrm{~m}^{2}$.

\section{Pemupukan}

Pupuk dasar berupa pupuk kandang dari kotoran ayam 20 ton/ha diberikan 2 minggu sebelum penanaman sebanyak $9,6 \mathrm{~kg} /$ plot dan pupuk anorganik berupa ponska $300 \mathrm{~kg} / \mathrm{ha}$ atau $144 \mathrm{~g} / \mathrm{plot}$ diberikan 2 kali yaitu saat penanaman dan saat tanaman berumur $15 \mathrm{hst}$ dan SP-36 $100 \mathrm{~kg} / \mathrm{ha}$ atau $48 \mathrm{~g} /$ petak diberikan saat penanaman atau pupuk dasar.

\section{Penamaman}

Penanaman dilakukan dengan cara ditugal dengan kedalaman 3-5 cm dan tiap lubang diisi 1 siung bawang. Bawang di tanam menggunakan jarak 20 × $20 \mathrm{~cm}$ (Muku, 2002).

\section{Penyiraman}

Penyiraman dilakukan setiap hari dengan menggunakan gembor atau menyesuaikan dengan kondisi cuaca saat penanaman.

\section{Penyulaman}

Penyulaman dilakukan setelah tanaman berumur 7-10 hari sesudah tanam. Tujuannya untuk mengganti tanaman yang tidak tumbuh/mati.

\section{Aplikasi Biourine}

Biourine diberikan dalam bentuk beberapa konsentrasi sesuai perlakuan penelitan (telah diencerkan terlebih dahulu dengan air) dan jumlah takaran yang diberikan adalah 7000 liter/ha (Adijaya, 2008) atau 3,6 liter/plot.

\section{Pengambilan Sampel dan Pengamatan}

Karakter yang diamati adalah : 1) Tinggi tanaman dilakukan mulai dari pangkal batang sampai ujung daun tertinggi yang diluruskan secara vertikal ke atas. Di ukur pada saat tanaman memasuki umur panen; 2) Jumlah daun dengan cara menghitung jumlah daun per tanaman pada setiap perlakuan; 3) Diameter umbi bawang diukur dengan menggunakan jangka sorong pada saat panen; 4) Jumlah umbi bawang per petak dihitung pada saat panen; 5) Berat segar umbi dengan daun per petak ditimbang saat panen; 6) Berat umbi kering dengan daun per petak ditimbang setelah umbi dikering anginkan selama 2 minggu. 


\section{Analisis Data}

Data yang diperoleh dianalisis dengan menggunakan analisis sidik ragam dan jika terdapat perbedaan antar perlakuan dilanjutkan dengan uji Beda Nyata Terkecil (BNT) pada taraf signifikan $5 \%$.

\section{HASIL DAN PEMBAHASAN}

\section{Tinggi Tanaman $(\mathrm{cm})$}

Berdasarkan hasil analisis sidik ragam $(p<0,05)$ perlakuan biourine dengan konsentasi $10 \%, 20 \%, 30 \%$ dan $40 \%$, hasilnya berbeda nyata dengan kontrol, sedangkan konsentasi $50 \%$ pertambahan tinggi tanaman tidak berbeda nyata dengan kontrol. Uji lanjut BNT $(0,05)$ pada Tabel 1 biourine dengan konsentrasi 20\% menghasilkan ratarata pertumbuhan tinggi tanaman tertinggi yaitu $33,29 \mathrm{~cm}$; diikuti konsentrasi $40 \%, 10 \%, 30 \%$ dan $50 \%$, dan terendah pada kontrol sebesar $26,59 \mathrm{~cm}$.

\section{Jumlah Daun}

Berdasarkan hasil analisis sidik ragam $(p<0,05)$ lima perlakuan biourine yang diberikan masing-masing $10 \%, 20 \%, 30 \%, 40 \%$ dan $50 \%$ menghasilkan pertambahan jumlah daunyang signifikan dibandingkan dengan kontrol. Uji lanjut $\mathrm{BNT}_{(0,05)}$ pada Tabel 2, biourine konsentrasi 20\% menghasilkan rata-rata pertambahan jumlah daun bawang merah tertinggi sebesar14,73 daun; diikuti konsentrasi $30 \%, 50 \%, 40 \%$ dan $10 \%$, dan terendah pada perlakuan kontrol sebesar 9,97 daun per tanaman.

\section{Jumlah Umbi}

Berdasarkan hasil analisis sidik ragam $(p<0,05)$ lima perlakuan biourine yang diberikan masing-masing $10 \%, 20 \%, 30 \%, 40 \%$ dan $50 \%$ menghasilkan pertambahan jumlah umbi yang signifikan dibandingkan dengan kontrol. Uji lanjut BNT $_{(0,05)}$ pada Tabel 3, biourine konsentrasi $30 \%$ menghasilkan rata-rata pertambahan jumlah umbi bawang merah tertinggi sebesar4,43 diikuti $20 \%$, dan $50 \%, 40 \%, 10 \%$ dan terendah pada kontrol sebesar 3,47 umbi/tanaman.

Tabel 1. Rata-rata Tinggi Tanaman Umur 56 hst pada Perlakuan Beberapa Konsentrasi Biourine

(Table 1. Average High Plant Age 56 Days After Planting On Treatment Several Concentrations Biourine)

\begin{tabular}{lc}
\hline Konsentrasi biourine & Tinggi tanaman $(\mathrm{cm})$ \\
\hline Kontrol (tanpa biourine) $\mathrm{B}_{0}$ & $26,59^{\mathrm{b}}$ \\
Biourine $10 \% \mathrm{~B}_{1}$ & $30,82^{\mathrm{a}}$ \\
Biourine $20 \% \mathrm{~B}_{2}$ & $33,29^{\mathrm{a}}$ \\
Biourine $30 \% \mathrm{~B}_{3}$ & $30,63^{\mathrm{a}}$ \\
Biourine $40 \% \mathrm{~B}_{4}$ & $32,92^{\mathrm{a}}$ \\
Biourine $50 \% \mathrm{~B}_{5}$ & $29,92^{\mathrm{ab}}$ \\
\hline BNT $(0,05)$ & 4
\end{tabular}

Ket: Notasi huruf yang berbeda pada masing-masing baris menunjukkan perbedaan yang nyata menurut uji $B N T_{(0,05)}$

Tabel 2. Rata-rata Jumlah Daun pada Beberapa Konsentrasi Biourine

(Table 2. Average Number of Leaves on some Concentration Biourine) Perlakuan Konsentrasi Biourine Rata-rata Jumlah Daun (helai per tanaman)

\begin{tabular}{ll}
\hline Kontrol (tanpa biourine) $\mathrm{B}_{0}$ & $9,97 \mathrm{~b}$ \\
Biourine $10 \% \mathrm{~B}_{1}$ & $12,67^{\mathrm{a}}$ \\
Biourine $20 \% \mathrm{~B}_{2}$ & $14,73^{\mathrm{a}}$ \\
Biourine $30 \% \mathrm{~B}_{3}$ & $13,63^{\mathrm{a}}$ \\
Biourine $40 \% \mathrm{~B}_{4}$ & $12,70^{\mathrm{a}}$ \\
Biourine $50 \% \mathrm{~B}_{5}$ & $12,93^{\mathrm{a}}$ \\
\hline BNT $(0,05)$ & 2,293 \\
\hline
\end{tabular}

Ket: Notasi huruf yang berbeda pada masing-masing baris menunjukkan perbedaan yang nyata menurut uji $B N T_{(0,05)}$ 
Tabel 3. Rata-rata Jumlah Umbi per Tanaman pada Beberapa Konsentrasi Biourine

(Table 3. Average Number of Tubers per Plant on Some Concentration Biourine)

\begin{tabular}{lc}
\hline \multicolumn{1}{c}{ Perlakuan Konsentrasi Biourine } & Rata-rata Jumlah Umbi per Tanaman \\
\hline Kontrol (tanpa biourine) $B_{0}$ & $3,47^{\mathrm{b}}$ \\
Biourine $10 \% \mathrm{~B}_{1}$ & $4,23^{\mathrm{a}}$ \\
Biourine $20 \% \mathrm{~B}_{2}$ & $4,40^{\mathrm{a}}$ \\
Biourine $30 \% \mathrm{~B}_{3}$ & $4,43^{\mathrm{a}}$ \\
Biourine $40 \% \mathrm{~B}_{4}$ & $4,30^{\mathrm{a}}$ \\
Biourine $50 \% \mathrm{~B}_{5}$ & $4,40^{\mathrm{a}}$ \\
\hline BNT & 2,23
\end{tabular}

Ket: Notasi huruf yang berbeda pada masing-masing baris menunjukkan perbedaan yang nyata menurut uji $B N T_{(0,05)}$

\section{Diameter Umbi}

Berdasarkan hasil analisis sidik ragam $(p<0,05)$ perlakuan biourine dengan konsentrasi $20 \%$, $40 \%$, dan $50 \%$ hasilnya berbeda nyata dengan kontrol, sedangkan perlakuan $10 \%$ dan $30 \%$ tidak berbeda nyata dengan kontrol. Uji lanjut BNT $_{(0,05)}$ pada Tabel 4, biourine konsentrasi $40 \%$ menghasilkan rata-rata pertambahan diameter umbi bawang merah tertinggi sebesar $1,35 \mathrm{~cm}$ diikuti diikuti konsentasi $20 \%$, dan $50 \%, 30 \%, 10 \%$, dan terendah pada kontrol sebesar $1,16 \mathrm{~cm} /$ tanaman.

\section{Berat Segar Umbi dengan Daun}

Berdasarkan hasil analisis sidik ragam $(p<0,05)$ biourine dibanding dengan kontrol, sebagaimana dilihat pada Tabel 5 . Lima perlakuan biourine yang diberikan masing-masing $10 \%, 20 \%$, $30 \%, 40 \%$ dan $50 \%$ menghasilkan pertambahan berat umbi segar dengan daun yang signifikan dibandingkan dengan kontrol.

Uji $\mathrm{BNT}_{(0,05)}$ padaTabel 5 , biourine dengan konsentrasi 50\% menghasilkan rata-rata pertambahan berat segar umbi dengan daun tertinggi sebesar 178,33 g per tanaman; diikuti konsetrasi $20 \%, 30 \%, 40 \% 10 \%$, dan terendah pada kontrol sebesar 145,33 g/tanaman.

\section{Berat Umbi Kering dengan Daun}

Berdasarkan hasil analisis sidik ragam $(p<0,05)$ perlakuan biourine dengan konsentrasi $20 \%$ memberikan pengaruh yang signifikan di- bandingkan dengan kontrol. Sedangkan empat perlakuan biourine $10 \%, 30 \%, 40 \%$ dan $50 \%$ tidak berbeda nyata dengan perlakuan kontrol. Uji BNT $(0,05)$ pada Tabel 6, biourine dengan konsentrasi $20 \%$ menghasilkan rata-rata pertambahan berat kering umbi bawang merah tertinggi sebesar $123,33 \mathrm{~g}$ per tanaman;diikuti konsentrasi $40 \%, 50 \%, 10 \%$ dan $30 \%$, dan terendah pada kontrol sebesar 96,00 g/tanaman.

\section{Tinggi Tanaman $(\mathrm{cm})$}

Peningkatan tinggi tanaman setelah ada penambahan biourine didukung dengan penelitian Adijaya (2008) dengan perlakuan biourine $20 \%$ tinggi tanaman bawang merah meningkat $19.56 \%$ $24.01 \%$ dibandingkan tanpa pemupukan. Penelitian lain yang mendukung terjadinya pertambahan tinggi tanaman bawang merah setelah ada penambahan biourine (Trisusiyo, dkk., 2014), dari hasil analisis ragam menunjukkan bahwa aplikasi biourine berpengaruh nyata. Panjang daun pada perlakuan biourine 1000 liter/ha pada pengamatan 56 hst, adalah $53,73 \mathrm{~cm}$ dan $51,59 \mathrm{~cm}$ pada perlakuan tanpa biourine.

Dari hasil yang diperoleh dalam penelitian ini konsentrasi $20 \%$ diikuti konsentrasi $40 \%, 10 \%$ dan $30 \%$ dan cenderung menurun pada konsentrasi $50 \%$. Menurut Foth (1994) penetapan konsentrasi dan dosis dalam pemupukan sangat penting dilakukan karena akan berpengaruh tidak baik pada pertumbuhan jika tidak sesuai kebutuhan tanaman. 
Tabel 4. Rata-rata Diameter Umbi pada Beberapa Konsentrasi Biourine

(Table 4. Average diameter Bulbs on Multiple Concentrations Biourine)

\begin{tabular}{lc}
\hline \multicolumn{1}{c}{ Perlakuan Konsentrasi Biourine } & Rata-rata Diameter umbi $(\mathrm{cm})$ \\
\hline Kontrol (tanpa biourine) $\mathrm{B}_{0}$ & $1,16^{\mathrm{b}}$ \\
Biourine $10 \% \mathrm{~B}_{1}$ & $1,24^{\mathrm{ab}}$ \\
Biourine $20 \% \mathrm{~B}_{2}$ & $1,34^{\mathrm{a}}$ \\
Biourine $30 \% \mathrm{~B}_{3}$ & $1,26^{\mathrm{ab}}$ \\
Biourine $40 \% \mathrm{~B}_{4}$ & $1,35^{\mathrm{a}}$ \\
Biourine $50 \% \mathrm{~B}_{5}$ & $1,34^{\mathrm{a}}$ \\
\hline BNT ${ }_{(0,05)}$ & 0,13 \\
\hline
\end{tabular}

Ket: Notasi huruf yang berbeda pada masing-masing baris menunjukkan perbedaan yang nyata menurut uji $B N T_{(0,05)}$

Tabel 5. Rata-rata Berat Umbi Segar dan Daun pada Beberapa KonsentrasiBiourine (Table 5. The Average Weight of Fresh Tubers and Leaves on Some Concentration Biourine)

\begin{tabular}{lc}
\hline \multicolumn{1}{c}{ Perlakuan Konsentrasi Biourine } & $\begin{array}{c}\text { Rata-rata Berat Umbi Segar dengan Daun } \\
\text { (g per tanaman) }\end{array}$ \\
\hline Kontrol (tanpa biourine) $\mathrm{B}_{0}$ & $145,33^{\mathrm{b}}$ \\
Biourine $10 \% \mathrm{~B}_{1}$ & $168,67^{\mathrm{a}}$ \\
Biourine $20 \% \mathrm{~B}_{2}$ & $177,67^{\mathrm{a}}$ \\
Biourine $30 \% \mathrm{~B}_{3}$ & $175,33^{\mathrm{a}}$ \\
Biourine $40 \% \mathrm{~B}_{4}$ & $174,67^{\mathrm{a}}$ \\
Biourine $50 \% \mathrm{~B}_{5}$ & $178,33^{\mathrm{a}}$ \\
\hline BNT $(0,05)$ & 15,81 \\
\hline Ket: Notasi huruf yang berbeda pada masing-masing baris menunjukkan perbedaan yang nyata menurut uji &
\end{tabular}

Tabel 6. Rata-rata Berat Kering Umbi pada Beberapa Konsentrasi Biourine

(Table 6. Average Dry Weight Bulbs on some Concentrations Biourine)

\begin{tabular}{lc}
\hline \multicolumn{1}{c}{ Perlakuan Konsentrasi Biourine } & $\begin{array}{c}\text { Rata-rata Berat Kering Umbi dengan Daun } \\
\text { (g per tanaman) }\end{array}$ \\
\hline Kontrol (tanpa biourine) $\mathrm{B}_{0}$ & $96,00^{\mathrm{b}}$ \\
Biourine $10 \% \mathrm{~B}_{1}$ & $105,67^{\mathrm{ab}}$ \\
Biourine $20 \% \mathrm{~B}_{2}$ & $123,33^{\mathrm{a}}$ \\
Biourine30\% B & $100,67^{\mathrm{ab}}$ \\
Biourine 40\% $\mathrm{B}_{4}$ & $118,33^{\mathrm{ab}}$ \\
Biourine50\% $\mathrm{B}_{5}$ & $109,67^{\mathrm{ab}}$ \\
\hline BNT ${ }_{(0,05)}$ & 23,41 \\
\hline
\end{tabular}

Ket: Notasi huruf yang berbeda pada masing-masing baris menunjukkanperbedaan yang nyata menurut uji $B N T_{(0,05)}$

Pertambahan tinggi tanaman tidak terlepas dari auksin yang terkandung dalam biourine yang dapat merangsang sel-sel meristem apikal batang dan pucuk batang (Leopold and Kriedeman, 1975), Auksin juga mengaktifkan pompa ion pada plasma membran sel sehingga dinding sel bertambah luas, tekanan plasma sel mengecil dan mengakibatkan air masuk ke dalam sel. Hal ini menyebabkan pembesaran dan pemanjangan sel (Wattimena, 1987). 


\section{Jumlah Daun}

Perlakuan beberapa konsentrasi biourine berpengaruh nyata pada parameter jumlah daun di banding dengan kontrol, yang tertinggi pada konsentrasi $20 \%$ diikuti konsentrasi $30 \%, 50 \%$ dan 10\%. Hal ini sejalan dengan penelitian (Trisusiyo $d k k ., 2014)$ bahwa aplikasi biourine berpengaruh nyata terhadap jumlah daun bawang merah umur 56 dan 70 hst. Sedangkan pada umur 14, 28, dan 42 hst aplikasi biourine tidak berpengaruh nyata.

Unsur hara $\mathrm{N}$ yang terkandung di dalam urine sapi sangat mempengaruhi dalam perkembangan daun sehingga menghasilkan jumlah daun yang berbeda. Sesuai pernyataan Lingga dan Marsono (2007) yang mengatakan bahwa peranan utama $\mathrm{N}$ bagi tanaman adalah untuk merangsang pertumbuhan secara keseluruhan, khususnya batang, cabang, dan daun. Selain itu $\mathrm{N}$ berperan penting dalam pembentukkan hijauan daun yang sangat berguna dalam proses fotosintesis.

Hal ini berhubungan juga dengan ketersediaan unsur hara dalam tanah yang mempengaruhi pertumbuhan tanaman dalam hal ini jumlah daun, tanaman tidak mendapatkan unsur tambahan $\mathrm{N}$ akan tumbuh kerdil dan daun terbentuk lebih kecil, lebih tipis dan sedikit jumlahnya, sedangkan tanaman yang menerima unsur $\mathrm{N}$ tumbuh lebih tinggi dan daun terbentuk lebih banyak dan luas (Poerwowidodo, 1992).

\section{Jumlah Umbi}

Perlakuan beberapa konsetrasi biourine berpengaruh nyata pada parameter jumlah umbi di banding dengan kontrol, yang tertinggi pada konsentrasi $30 \%$, diikuti konsentrasi $20 \%$ dan $50 \%$, $40 \%$ dan $10 \%$. Hal ini sejalan dengan penelitian Adijaya (2008) dengan pemberian biourine jumlah umbi bawang merah per tanaman meningkat dari 5.56 umbi pada tanpa pemupukan menjadi 6,65 umbi pada pemberian kompos RB $10 \mathrm{tha}^{-1}, 6,8$ umbi pada perlakuan urin sapi $15.000 \mathrm{I} \mathrm{ha}^{-1}$ dan 6,82 pada kombinasi kompos RB 5 t ha $^{-1}$ dan urin sapi $7.500 \mathrm{I} \mathrm{ha}^{-1}$.

Peningkatan pertumbuhan dan produksi bawang merah akibat penambahan $\mathrm{N}$ yang berasal dari biourine, ini berkaitan erat dengan peran $\mathrm{N}$ dalam meningkatkan laju pertumbuhan tanaman.
Engelstad (1997) mengatakan bahwa aplikasi N yang optimal dapat meningkatkan pertumbuhan tanaman, meningkatkan sintesis protein, pembentukan klorofil yang menyebabkan warna daun menjadi lebih hijau, dan meningkatkan rasio akar. Jumlah anakan sangat mempengaruhi jumlah umbi pada tanaman. Semakin banyak jumlah anakan, maka semakin banyak pula jumlah umbi yang dihasilkan. Ketersediaan nutrisi pada tanaman dapat mempengaruhi jumlah anakan pada tanaman.

\section{Diameter Umbi}

Perlakuan beberapa konsentrasi biourine berpengaruh nyata pada diameter umbi di banding dengan kontrol, yang tertinggi pada konsentrasi $40 \%$, konsentrasi $20 \%$, dan $50 \%$ dengan nilai yang sama, dan diikuti konsentrasi $30 \%$ dan $10 \%$. Hasil analisis sidik ragam antar perlakuan konsentrasi biourine sapi $20 \%, 40 \%$ dan $50 \%$ berbeda nyata dengan kontrol sedangkan konsetrasi $10 \%$ dan $30 \%$ tidak berbeda nyata dengan kontrol. Hasil penelitian ini di dukung oleh (Trisusiyo, dkk., 2014) yang menyatakan bahwa aplikasi biourine 1000 liter per ha, berpengaruh nyata terhadap jumlah anakan bawang merah. Pada pengamatan 56 hst, dengan perlakuan biourine, jumlah anakan 16,39 per tanaman dan tanpa biourine 14,79 per tanaman. Jumlah anakan sangat mempengaruhi pada jumlah umbi pada tanaman. Semakin banyak jumlah anakan maka umbi yang dihasilkan pada tanaman semakin banyak. Pemberian nutrisi pada tanaman dapat mempengaruhi jumlah anakan pada tanaman.

\section{Berat Umbi Segar dengan Daun}

Hasil analisis sidik ragam antar perlakuan biourin konsetrasi 10\%, 20\%,30\%, 40\% dan 50\% memberikan pengaruh nyata pada berat umbi segar dan daun dibanding dengan perlakuan kontrol. Biourine konsentrasi $50 \%$ tertinggi diikuti $20 \%$, $30 \%, 40 \%$ dan $10 \%$. Hasil ini didukung dengan penelitian (Ni Kadek, dkk., 2013). Pengaruh pemberian konsentrasi biourine terhadap parameter berat segar bagian atas tanaman bayam nilai tertinggi diperoleh pada perlakuan (U2/Konsentrasi $30 \%$ atau $300 \mathrm{ml}$ biourine dalam 1 liter larutan) dibandingkan dengan kontrol sebagai nilai terendah memiliki peningkatan sebesar $15,44 \%$. 
Penambahan kalium lewat biourine sapi pada bawang merah mempengaruhi pertumbuhan, hasil dan kualitas umbi. Defisiensi kalium dapat menghambat pertumbuhan, penurunan ketahanan dari penyakit, dan menurunkan hasil bawang merah (Singh and Verma, 2001). Peningkatan berat basah dan berat kering tanaman di tanaman bawang karena hormon yang terkandung dalam biourine. Wattimena (1987) menjelaskan bahwa auksin akan meningkatkan kandungan zat organik dan anorganik dalam sel. Selanjutnya, zat ini diubah menjadi protein, asam nukleat, polisakarida, dan molekul kompleks lainnya. Senyawa tersebut akan membentuk jaringan dan organ, sehingga berat basah dan berat kering tanaman meningkat.

\section{Berat Umbi Kering dengan Daun}

Hasil analisa sidik ragam pengaruh perlakuan biourine sapi pada konsentrasi $20 \%$ berbeda nyata dengan perlakuan kontrol, sedangkan perlakuan $10 \%, 30 \% 40 \%$ dan $50 \%$ tidak berbeda nyata dengan perlakuan kontrol, tetapi memperlihatkan kecenderungan peningkatan berat kering. Hasil penelitian (Trisusiyo, dkk., 2014), menyatakan bahwa aplikasi biourine 1000 liter/ha, berpengaruh nyata terhadap berat umbi bawang kering matahari. Pada pengamatan $84 \mathrm{hst}$, dengan perlakuan biourine, berat kering umbi $2938,89 \mathrm{~g}$ meter/segi dan tanpa biourine $2111,85 \mathrm{~g}$ meter/segi.

Yuliarta (2014) yang menyatakan bahwa hasil kombinasi biourine dengan pupuk anorganik mendapatkan hasil tanaman padi yang tertinggi, pada perlakuan (B1) biourine dan aplikasi pupuk anorganik (P1) $300 \mathrm{~kg} / \mathrm{ha}$ urea, $100 \mathrm{~kg} / \mathrm{ha}$ SP-36, $150 \mathrm{~kg} / \mathrm{ha} \mathrm{KCl}$. Perlakuan B1 dan P1 mendapatkan hasil tertinggi dari semua parameter pengamatan komponen hasil padi yang meliputi, jumlah malai per rumpun, jumlah bulir per malai, berat 1000 butir, berat bulir per rumpun, serta berat kering tanaman per rumpun.

Secara umum perlakuan yang mengkombinasikan biourine sapi dengan pupuk anorganik menunjukkan kecenderungan peningkatan hasil tanaman (tinggi, jumlah daun, jumlah umbi, diameter umbi, berat segar dan berat umbi kering) yang lebih tinggi dibanding dengan tanpa biourine. Hal ini disebabkan karena biourineyang diberikan ke tana- man disamping mengandung unsur makro seperti $\mathrm{N}, \mathrm{P}, \mathrm{K}, \mathrm{Ca}, \mathrm{Mg}, \mathrm{S}$ juga mengandung unsur mikro seperti $\mathrm{Mn}, \mathrm{Zn}, \mathrm{Fe}, \mathrm{Cu}, \mathrm{Cl}$ yang banyak diperlukan oleh tanaman (Musnamar, 2003).

\section{KESIMPULAN}

Pupuk organik dari biourine sapi memberikan pengaruh terhadap peningkatan pertumbuhan dan produksi bawang merah.

Perlakuan konsentrasi biourine 10\%, 20\%, $30 \%, 40 \%$, dan $50 \%$ yang diuji, semuanya dapat meningkatkan tinggi tanaman, jumlah daun, jumlah umbi, diameter umbi, berat umbi segar dengan daun dan berat umbi kering dengan daun. Umbi kering dengan daun dicapai pada perlakuan konsentrasi biourine 20\%, 40\%, 50\% dan 10\% masingmasing sebesar $123,33 \mathrm{~g}$ per tanaman, $118,22 \mathrm{~g}$ per tanaman, 109,67 g per tanaman dan 105,67 g per tanaman.

\section{DAFTAR PUSTAKA}

Adijaya I Nyoman. 2008. Respon Bawang Merah terhadap Pemupukan Organik di Lahan Kering. Karya IImiah. Balai Pengkajian Teknologi Pertanian Bali.Denpasar. Jurnal Widya riset. http://widyariset.pusbindiklat. lipi.go.id/index.php/widyariset/article/viewFi le/220/212.

Badan Litbang Pertanian. 2013b. http://balitsa. litbang.deptan.go.id/ind/index.php/beritaterbaru/170-panen.html, tgl akses 23 Oktober 2013.

Dinas Pertanian dan Peternakan Provinsi Sulawesi Utara. 2014. Data Luas Lahan Pertanian dan Potensi Lahan Hortikultura di Sulawesi Utara.

Engelstad. 1997. Teknologi dan Penggunaan Pupuk. UGM Press.Yogyakarta. HIm. 293322

Foth, D. Hendry. 1994. Dasar-Dasar IImu Tanah. Edisi ke-enam. Diterjemahkan oleh 
Soenartono Adisoemarto. Erlangga. Jakarta.

Leopold, A.C. and P.E. Kriedeman. 1975. Plant Growth and Development, Second Edition, Tata Mac Graw Hill, Publishing Company Ltd. New Delhi. Journal of Experimental Botany 26(95): 939-942.

Lingga, P. dan Marsono. 2007. Petunjuk Penggunaan Pupuk. Penebar Swadaya. Jakarta.

Muku, O. 2002. Pengaruh Jarak Tanam Antar Barisan dan Macam Pupuk Organik Terhadap Pertumbuhan dan Hasil Tanaman Bawang Merah (Allium ascalonicum $\mathrm{L}$ ) di Lahan Kering. Tesis. Program Pasca Sarjana Universitas Udayana, Denpasar Bali.

Musnamar, E. I. 2003. Pupuk Organik; Cair dan Padat, Pembuatan, Aplikasi. Cetakan Pertama. Penebar Swadaya. Jakarta.

Ni Kadek Shinta Dharmayanti, A. A. Nyoman Supadma dan I Dewa Made Arthagama. 2013. Pengaruh Pemberian Biourinedan Dosis Pupuk Anorganik (N,P,K) Terhadap Beberapa Sifat Kimia Tanah Pegok dan Hasil Tanaman Bayam (Amaranthus sp.)EJurnal Agroekoteknologi Tropika ISSN: 2301-6515 Vol. 2, No. 3, Juli 2013.

Poerwowidodo. 1992. Telaah Kesuburan Tanah. Angkasa. Bandung.

Pustaka Indonesia. 2011. http://hasil-indonesia. blogspot.com/2011/01/membuat-pupukdari-urine-sapi.html, diakses tanggal 23 Juni 2015.
Singh, S. P and A.B. Verma. 2001. Response of onion (Allium cepa) to Potassium Application. Indian Journal of Agronomy. 46(1): 182-185.

Sutari, N. W. S. 2010. Pengujian Kualitas Biourine Hasil Fermentasi dengan Mikroba yang Berasal dari Bahan Tanaman Terhadap Pertumbuhan dan Hasil Tanaman Sawi Hijau (Brassica juncea L.). Tesis. Program Studi Bioteknologi Pertanian, Program Pascasarjana, Fakultas Pertanian, Universitas Udayana, Denpasar.

Trisusiyo Wati, Y. Euis Elih Nurlaelih dan Mudji Santosa. 2014. Pengaruh Aplikasi Urine pada Pertumbuhan dan Hasil Bawang Merah (Allium ascalonicum L.). Jurnal Produksi Tanaman Volume 2, Nomor 8, Desember 2014, hlm. 613-619.

Waluyo Nurmalita dan Rismawita Sinaga. 2015. Bawang Merah yang di Rilis oleh Balai Penelitian Sayuran. Iptek Tanaman Sayuran No. 004, Januari 2015. Tanggal diunggah 21 Januari 2015.

Watimena, G.A. 1987. Zat Pengatur Tumbuh Tanaman. PAU Bioteknologi IPB Bogor

Wibowo, S. 1990. Budidaya Bawang Putih, Bawang Merah dan Bawang Bombay. Penebar Swadaya. Jakarta.

Yuliarta, B. 2014. Pengaruh Biourine Sapi dan Berbagai Dosis Pupuk NPK terhadap Pertumbuhan dan Hasil Tanaman Selada Krop (Lactuca Sativa L). Jurnal Produksi Tanaman 1(6):1-10. 